\title{
HUBUNGAN KEPADATAN TERIPANG (HOLOTHUROIDEA) DENGAN KERAPATAN LAMUN DI PERAIRAN PULAU BUNTAL-TELUK KOTANIA, KABUPATEN SERAM BAGIAN BARAT
}

\section{The Relation of Sea Cucumber Density (Holothuroidea) with Seagrass Density in The Waters of Buntal Island-Kotania Bay, District of West Seram}

\author{
${ }^{1)}$ Mahasiswa Program Studi Magister Ilmu Kelautan Pascasarjana Universitas Pattimura \\ 2) Jurusan Manajemen Sumberdaya Perairan Fakultas Perikanan dan Ilmu Kelautan Universitas Pattimura \\ 3) Jurusan Manajemen Sumberdaya Perairan Fakultas Perikanan dan Ilmu Kelautan Universitas Pattimura \\ *bachmidsakti123@gmail.com, laura.siahainenia@gmail.com,lotjetupan@yahoo.com \\ Corresponding author*
}

\begin{abstract}
ABSTRAK: Pulau buntal memiliki potensi sumberdaya lamun maupun teripang yang melimpah. Ekosistem lamun sebagai habitat bagi sumberdaya teripang yang merupakan salah satu biota berekonomis penting. Tujuan dari penelitian ini adalah: 1) mengetahui kondisi lingkungan; 2) mengetahui kondisi lamun; 3) mengetahui struktur komunitas teripang; 4) mengetahui distribusi spasial teripang pada ekosistem lamun; 5) menganalisis hubungan kepadatan teripang dengan kerapatan lamun di perairan Pulau Buntal-Teluk Kotania, Kabupaten Seram Bagian Barat. Pengambilan sampel lamun dan teripang dilakukan secara sistematik menggunakan metode Belt Transek. Lokasi penelitian terdiri dari 2 stasiun pengamatan dan setiap stasiun terbagi menjadi 3 zona. Kondisi lamun yang dianalisis meliputi kerapatan, frekuensi kehadiran dan persentase tutupan lamun. Struktur komunitas teripang meliputi kepadatan dan frekuensi kehadiran. Peta distribusi spasial teripang pada ekosistem lamun menggunakan aplikasi ArcGIS. Analisis regresi linear sederhana dan korelasi pearson untuk melihat pengaruh serta hubungan kepadatan teripang dengan kerapatan lamun. Berdasarkan hasil penelitian menunjukan bahwa sacara keseluruhan parameter lingkungan di perairan Pulau Buntal sangat mendukung untuk kehidupan sumberdaya lamun maupun teripang. Ditemukannya lima jenis lamun dan 11 jenis teripang. Thalassia hemprichii merupakan jenis lamun yang sangat mendominasi pada komunitas lamun di perairan Pulau buntal. Jenis teripang Holothuria leucospilota dan H. atra memiliki nilai kepadatan yang tinggi pada perairan pulau Buntal. Dengan kondisi lamun sehat (tutupan baik) pada stasiun 1 dan tidak sehat (tutupan rusak) pada stasiun 2. Hubungan kepadatan teripang dengan kerapatan lamun pada Perairan Pulau Buntal dapat disimpulkan terdapat hubungan yang tinggi sehingga semakin tinggi kerapatan lamun akan diikuti oleh tingginya kepadatan teripang.
\end{abstract}

Kata Kunci: Lamun, teripang, kepadatan, ekosistem lamun, Pulau Buntal

ABSTRACT: Buntal island has rich potency of both seagrass and sea cucumber. Seagrass ecosystem is the habitat of one among the economic valued biota, sea cucumber. The purpose of the research are: 1) to know the environmental condition; 2) to know the seagrass condition; 3) to know the community structure of the sea cucumber; 4) to know the spatial distribution of sea cucumber in the seagrass ecosystem; and 5) to analyze the relation of the density of sea cucumber and the density of seagrass in the waters of Buntal island-Kotania Bay, West Seram Regency. The sample are taken systematically using Belt Transect. The research is located in 2 observation stations where each station is determines into 3 zones. 
Seagrass condition is analyzed consist of density, frequency of presence and percentage of seagrass cover. The community structure of sea cucumber includes the density and frequency of presence. Spatial distribution mapping on the sea grass ecosystem is using ArcGIS application. The simple linear regression analysis and Pearson correlation are used to analyze the relation between the density of the sea cucumber and the density of the seagrass. The result of the research shows that the whole environmental parameters on the waters of Buntal Island support the existence of both the seagrass and the sea cucumber. The research finds 5 varieties of seagrass and 11 varieties of sea cucumber. Thalassia hemprichii is the seagrass variety that dominates the ecosystem while Holothuria leucospilota and $H$. atra are the varieties of sea cucumber with high density on Buntal Island waters. The healthy seagrass condition (well covered) is found in station 1 and bad health condition (worse covered) is found in station 2. The relation between the density of sea cucumber and the density of seagrass on the waters of Buntal Island, it is concludes that there is a high relation where the higher the density of seagrass the higher the density of the sea cucumber.

Key Words: Seagrass, sea cucumber, density, seagrass ecosystem, Buntal Island

\section{PENDAHULUAN}

Teripang atau yang dikenal sebagai mentimun laut atau sea cucumber termasuk hewan laut yang berbadan lunak yang berbentuk memanjang seperti mentimun. Hewan ini termasuk dalam kelas holothuroidea dari filum echinodermata yang merupakan hewan tidak bertulang belakang dan bertubuh lunak atau berduri (Suryaningrum, 2008). Beberapa spesies teripang ada yang mempunyai duri/bintil dan ada yang tidak berduri/berbintil, yang sebenarnya duri atau bintil merupakan rangka atau skelet yang tersusun dari zat kapur dan terdapat di dalam kulitnya (Kordi, 2011).

Teripang memiliki peranan secara ekologis maupun ekonomis. Secara ekologis teripang termasuk dalam lingkar pangan (food web) dan berperan sebagai deposit feeder, sehingga dapat mengolah substrat yang ditempatinya. Selain itu, teripang berperan sebagai penyedia pangan dalam bentuk telurtelur, larva dan juwana teripang, bagi biota laut pemangsa di sekitarnya (Darsono, 2003; Kordi 2010). Berkurangnya populasi teripang secara cepat menimbulkan konsekuensi bagi kelangsungan hidup berbagai jenis biota lain yang merupakan bagian dari kompleksitas lingkar pangan yang sama (Lewerissa, 2014). Secara ekonomis teripang peran ekonomis bahan makanan yang memiliki kandungan nutrisi yang sangat tinggi. Dalam kondisi kering, teripang mengandung protein sebanyak
$82 \%$, lemak $1,7 \%$, kadar air $8,9 \%$, kadar abu $8,6 \%$, dan karbohidrat $4.8 \%$ (Martoyo et al., 2006).

Pada umumnya, teripang dapat ditemui pada ekosistem padang lamun (Oktamalia, $d k k$., 2016; Laksana, dkk., 2019). Ekosistem lamun (seagrass) adalah satu dari tiga ekosistem khas daerah tropis yang dikenal sebagai 'keystone ecosystems' bersama ekosistem mangrove dan terumbu karang. Ketiga ekosistem ini merupakan penyangga (buffer) bagi kehidupan di laut dan darat, karena berada pada daerah peralihan antara laut dan darat. Ekosistem lamun juga merupakan habitat (tempat hidup) berbagai biota bernilai ekonomi tinggi, seperti ikan, teripang, kima, siput, dan bulu babi dan lainnya (Riniatsih, 2016; Jalaluddin, dkk., 2020). Lamun (seagrass) adalah salah satu kelompok tumbuh-tumbuhan berbunga yang berada di lingkungan laut. Lamun (seagrass) tumbuh subur terutama pada daerah terbuka pasang surut dan perairan pantai yang dasarnya berupa lumpur, pasir, kerikil dan patahan karang mati. Pola penyebaran lamun sangat tergantung pada topografi dasar pantai, kandungan nutrient dasar perairan dan beberapa faktor fisik serta kimia lainnya (Ati, $d k k$., 2016; Parawansa, $d k k$., 2020).

Pulau Buntal terletak di sebelah selatan Pulau Osi, padang lamun yang terdapat di pulau ini, sangat luas hampir seluruh areal pasang surut merupakan padang lamun. Ekosistem 
padang lamun ditemukan mengelilingi pulau Buntal dengan substrat yang bervariasi meliputi: pasir berlumpur, pasir kasar, dan patahan karang, sehingga mempengaruhi sebaran spasial vegetasi lamun dengan kerapatan yang berbeda, dengan membentuk vegetasi multispesifik (Latuconsina $d k k$, 2014). Lamun mempunyai fungsi yaitu sebagai tempat mencari makan (feeding ground), daerah asuhan (nursery ground) dan daerah pembesaran bagi sejumlah organisme (Dahuri dkk., 2004; Azkab, 2006). Kondisi dan keberadaan lamun di perairan Oulau Buntak ini menunjang kehadiran teripang. Selain itu juga, terdapat aktivitas pemanfaatan teripang yang dilakukan oleh masyarakat dari Dusun Kotania dan hanya sebagian kecil dari masyarakat di Dusun Wael.

Masyarakat Dusun Kotania dan sebagain dari masyarakat Dusun Wael sering memanfaatkan teripang yang umumnya masih bersifat tradisional. Masyarakat mengumpulkan sedikit demi sedikit teripang tersebut hingga jumlah tertentu kemudian dijual kepada pengumpul. Seiring dengan meningkatnya permintaan teripang sebagai komoditi ekspor mengakibatkan perburuan teripang semakin meningkat. Oleh karena itu tidak mengherankan jika pemanfaatan biota tersebut dari habitatnya ekosistem lamun cenderung dilakukan secara intensif tanpa memperhatinkan kelestarian dan penyebarannya di alam. Adapun tujuan dilakukannya penelitian ini adalah: (1) mengetahui kondisi lingkungan; (2) mengetahui kondisi lamun; (3) mengetahui struktur komunitas teripang; (4) mengetahui distribusi spasial teripang pada ekosistem lamun; (5) menganalisis hubungan kepadatan teripang dengan kerapatan lamun di perairan Pulau Buntal-Teluk Kotania, Kabupaten Seram Bagian Barat.

\section{METODE PENELITIAN}

Penelitian ini dilakukan pada bulan Maret 2020 yang berlokasi di perairan Pulau BuntalTeluk Kotania, Kabupaten Seram Bagian Barat
(Gambar 1). Pengambilan data mengenai parameter lingkungan fisik kimia di lokasi penelitian mencakup tipe substrat, suhu, $\mathrm{pH}$ dan salinitas. Pengambilan sampel lamun dilakukan secara sistematik menggunakan metode Belt Transek menurut Smith (1980) dalam Khouw (2009). Lokasi penelitian terdiri dari dua stasiun pengamatan. Setiap stasiun terbagi menjadi tiga zona dan terdiri dari tiga garis transek yang masing-masing tegak lurus garis pantai ke arah laut. Panjang setiap garis transek $\pm 100 \mathrm{~m}$ dan jarak antar setiap garis transek \pm 50 $m$ dengan kuadran yang digunakan berukuran $1 \mathrm{x} 1 \mathrm{~m}$.

Posisi geografis setiap transek dan kuadran ditentukan dengan menggunakan GPS (Global Positioning System). Pengamatan dan pengambilan sampel dilakukan pada malam hari saat keadaan air surut untuk memudahkan pengamatan serta perhitungan sampel lamun. Sampel lamun yang diamati kemudian dicatata jenis dan jumlah tegakan dari setiap jenis-jenis lamun yang berada di dalam kuadran dan diambil satu individu lamun dari masing-masing jenis lamun sebagai sampel.

Pengambilan sampel teripang bersamaan dengan lamun menggunakan kuadran $5 \times 5 \mathrm{~m}$. Setiap biota teripang yang terdapat dalam kuadrat tersebut dicatat jumlah jenis dan jumlah individunya. Tiap spesies teripang yang ditemukan pada kuadrat sepanjang transek dikoleksi 1 individu per spesies sebagai sampel untuk diidentifikasi. Sampel tiap spesies teripang dimasukkan dalam kantong plastik dan diawetkan dengan alkohol $70 \%$.

Lamun diidentifikasi dengan mengamati ciri morfologisnya dengan menggunakan buku kunci identifikasi yang dikemukakan Den Hartog (1970), Azkab (1999), dan Phillips\&Menez (1988). Sampel teripang diidentifikasi dengan mengamati morfologinya berdasarkan panduan oleh Clark\&Rowe (1971) dan Cannon\&Silver (1987). Analisis kondisi padang lamun didasarkan pada petunjuk English et al. (1997) sebagai berikut: 


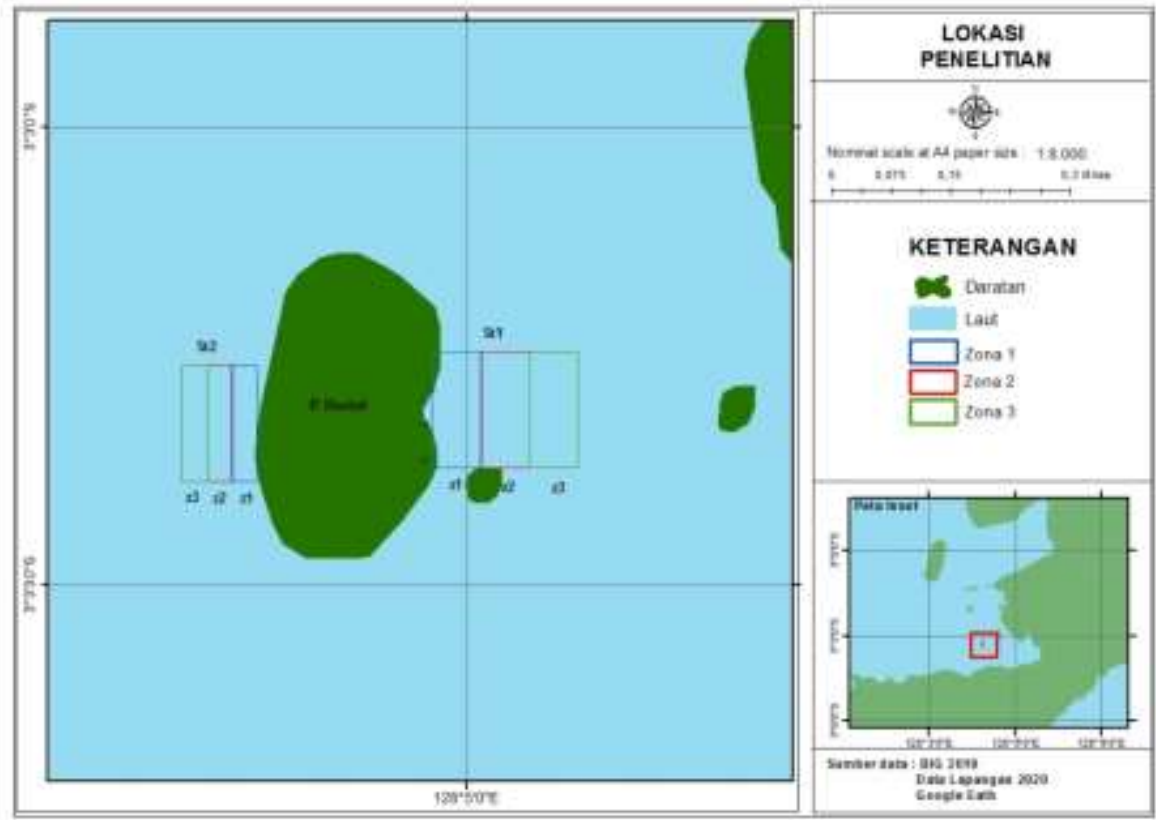

Gambar 1. Peta Lokasi Penelitian

- Kerapatan jenis dan kerapatan relatif jenis lamun

$$
\mathrm{DI}=\mathrm{ni} / \mathrm{A}
$$

Ket :

Di $=$ kerapatan jenis ke-i (ind $/ \mathrm{m}^{2}$ )

ni $=$ jumlah total individu jenis ke-i (ind.) per transek

$\mathrm{A}=\underset{2}{\operatorname{luas}}$ area total pengambilan contoh $(\mathrm{m})$ seluruh transek

Ket :

$$
\mathrm{RD}=\mathrm{Di} / \Sigma \mathrm{Di} \times 100
$$

$\mathrm{RDi}=$ kerapatan relative jenis ke- $\mathrm{i}$

$$
\begin{aligned}
\mathrm{Di}= & \begin{array}{l}
\text { kerapatan } \\
\text { transek }
\end{array} \\
\Sigma \mathrm{D}= & \text { jumlah }{ }^{2} \text { kerapatan } \text { keluruh jenis } \\
& \left(\mathrm{ind} / \mathrm{m}^{2}\right) \text { seluruh transek }
\end{aligned}
$$

- Frekuensi jenis dan frekuensi relatif jenis lamun

Ket :

$$
\mathrm{Fi}=\mathrm{Pi} / \Sigma \mathrm{Pi}
$$

$\mathrm{Fi}=$ frekuensi jenis ke-i

$\mathrm{Pi}=$ jumlah petak contoh ditemukannya jenis ke-I per transek

$\Sigma \mathrm{Pi}=$ jumlah total petak contoh yang diamati seluruh transek

$$
\mathrm{RFi}=\mathrm{Fi} / \Sigma \mathrm{Fi} \times 100
$$

Ket :

$\mathrm{RFi}$ = frekuensi relative jenis ke-i

$\mathrm{Fi}=$ frekuensi jenis ke-I per transek

$\Sigma \mathrm{F}=$ jumlah total frekuensi jenis seluruh transek

- Penutupan jenis dan penutupan relative jenis lamun

$$
\mathrm{Ci}=\sum(M i x f i) / \sum f
$$

Ket :

$\mathrm{Ci}=$ penutupan jenis ke-i

$\mathrm{Mi}=$ persentase nilai tengah kelas ke- $\mathrm{i}$

fi $=$ frekuensi (jumlah tutupan kotak - kotak kecil dari jenis ke-i, yang dominan)

$\Sigma f=$ jumlah total frekuensi jenis ke-i

Ket :

$$
\mathrm{RCi}=\mathrm{Ci} / \Sigma \mathrm{Ci} \times 100 \%
$$

Rci $=$ penutupan relative jenis ke-i

$\mathrm{Ci}=$ penutupan jenis ke-i

$\Sigma \mathrm{Ci}=$ jumlah total penutupan

- Analisa data kepadatan dan frekuensi kehadiran teripang digunakan formula (Odum, 1971) :

$$
D i=\frac{n i}{A}
$$


Ket :

$\mathrm{Di}=$ kepadatan jenis (individu/ $1 \mathrm{~m}^{2}$ )

$\mathrm{Ni}=$ jumlah total individu jenis (individu)

$\mathrm{A}=$ luas area yang di sampling $\left(\mathrm{m}^{2}\right)$

$$
F i=\frac{p i}{\sum p}
$$

Ket:

$\mathrm{Fi}=$ frekuensi jenis

pi $=$ jumlah petak contoh dimana ditemukan jenis $\mathrm{i}$

$\sum p=$ jumlah total petak contoh yang diamati

- Potensi sumberdaya teripang dihitunga menggunakan formula sebagai berikut (Lewerissa, 2014), yaitu :

$$
\begin{aligned}
& \text { Potensi }(\text { Ind })= \text { Kepadatan }\left(\mathrm{ind} / \mathrm{m}^{2}\right) \times \text { Luas } \\
& \text { area }\left(\mathrm{m}^{2}\right)
\end{aligned}
$$

- Distribusi spasial teripang dianalisis menggunakan metode pemetaan dengan aplikasi ArcGIS. Dalam menganalisis hubungan kerapatan lamun dengan kepadatan teripang maka digunakan regresi linear sederhana untuk melihat besar atau kecilnya pengaruh kerapatan lamun terhadap kepadatan teripang, serta analisis korelasi pearson untuk melihat seberapa erat hubungannya.

- Analisis Regresi Linear

$$
\mathrm{Y}=\mathrm{a}+\mathrm{bx}
$$

Ket:

$\mathrm{Y}=$ Kepadatan teripang dalam variable dependen yang di prediksikan

$\mathrm{a}=$ nilai $\mathrm{Y}$ bila $\mathrm{X}=0$ (nilai konstan)

$\mathrm{b}=$ nilai koefisien regresi, yang menunjukkan nilai peningkatan atau penurunan

- Analisis Korelasi Pearson

$$
r=\frac{\mathrm{n} \sum_{i=1}^{n} \mathrm{xiyi}-\left(\sum_{i=1}^{n} \mathrm{xi}\right)\left(\sum_{i=1}^{n} \mathrm{yi}\right)}{\sqrt{\left[\mathrm{n} \sum_{i=1}^{n} \mathrm{xi}^{2}-\left(\sum_{i=1}^{n} \mathrm{xi}\right)^{2}\right]\left[\mathrm{n} \sum_{i=1}^{n} \mathrm{yi}^{2}-\left(\sum_{i=1}^{n} \mathrm{yi}\right)^{2}\right]}}
$$

Hipotesis yang dikembangkan yakni:

- Ho: Tidak ada hubungan antara kepadatan teripang dengan kerapatan lamun di perairan Pulaul Buntal - Teluk Kotania, Kabupaten Seram Bagian Barat

- Ha: Ada hubungan antara kepadatan teripang dengan kerapatan lamun di perairan Pulaul Buntal - Teluk Kotania, Kabupaten Seram Bagian Barat

Jika nilai $\mathrm{t}$ hitung lebih besar dari $\mathrm{t}$ tabel maka Ho ditolak; Ha diterima, dan sebaliknya.

\section{HASIL DAN PEMBAHASAN}

\section{Parameter Lingkungan Perairan \\ Suhu}

Suhu yang diperoleh pada kedua stasiun berkisar antara $28^{\circ} \mathrm{C}-31^{\circ} \mathrm{C}$. Suhu pada perairan Pulau Buntal tidak memiliki perbedaan yang begitu jauh dikarenakan waktu pengambilan sampel yang dilakukan pada malam hari. Suhu yang baik untuk kehidupan teripang berkisar antara $22^{\circ} \mathrm{C}-32^{\circ} \mathrm{C}$ (Satria, et al., 2014). Selain untuk menunjang kehidupan teripang, suhu perairan juga merupakan faktor penunjang pertumbuhan lamun dan terumbu karang. Parameter suhu dapat mempengaruhi proses fotosintesis. Suhu yang berada di luar kisaran baku mutu dapat mengakibatkan proses fotosintesis menurun secara tajam (Poedjirahajoe, $d k k .$, 2013). Berdasarkan baku mutu air laut untuk biota laut (KepmenLH 51 tahun 2004), suhu bagi pertumbuhan lamun berkisar antara $28-30^{\circ} \mathrm{C}$.

\section{Salinitas}

Nilai salinitas yang ditemukan berdasarkan hasil pengukuran di kedua stasiun pengamatan yaitu berkisar antara 31\%o-33\%o. Beberapa penelitian menyatakan kisaran suhu bagi pertumbuhan teripang berkisar antara 3137 ppt (Martoyo, $d k k$., 2006; Padang $d k k$., 2017; Marsoedi, $d k k .$, 2020). Menurut Dahuri (2001) jenis lamun memiliki toleransi terhadap salinitas yang berbeda pada kisaran 10-40\%o, dengan nilai optimum toleransi salinitas air laut yang baik bagi pertumbuhan lamun sebesar 35\% . Lamun sebagai tumbuhan tingkat tinggi yang hidup di laut memiliki toleransi salinitas yang lebar (euryhaline) dengan adaptasi morfologi daun yang memiliki kutikula tipis sehingga 
daun mampu mengabsorbsi nutrien secara langsung di perairan (Badria, 2007).

\section{pH}

Hasil pengukuran nilai $\mathrm{pH}$ perairan diperoleh hasil rata-rata sebesar 7,9 dengan kisaran antara 7,8-8. Menurut (Kordi, 2011), kisaran $\mathrm{pH}$ yang cocok pertumbuhan teripang adalah 6,5-8,5. Hasil pengukuran $\mathrm{pH}$ menunjukkan tidak ada perbedaan yang signifikan antara stasiun 1 dan 2. Pada kisaran $\mathrm{pH}$ tersebut dapat disimpulkan bahwa stasiun 1 dan stasiun $2 \mathrm{~d}$ kategorikan dalam perairan mendukung pertumbuhan teripang maupun lamun.

\section{Komposisi Jenis Lamun}

Berdasarkan hasil penelitian yang dilakukan di perairan Pulau Buntal ditemukan lima jenis lamun yang tergolong atas dua famili dan empat genus yaitu jenis lamun Enhalus acoroides, Thalassia hemprichii, Halophila ovalis, Cymodocea rotundata dan Cymodocea serrulata (Tabel 1). Jenis lamun yang diperoleh memiliki kesamaan jika dibandingkan dengan penelitian Wawo, et al (2014) di lokasi Teluk Kotania. Jenis lamun Enhalus acoroides dan Thalassia hemprichii merupakan jenis utama pada perairan Pulau Buntal karena kedua jenis ini ditemukan hampir pada seluruh kuadran maupun zona dari kedua stasiun.

\section{Kerapatan Jenis Lamun Tiap Stasiun dan Zona}

Nilai kerapatan tertinggi dan kerapatan relatif pada stasiun 1 diwakili oleh jenis Thalassia hemprichii masing-masing sebesar 147,6 tegakan $/ \mathrm{m}^{2}$ dan $41 \%$ (Gambar 1). Hal ini disebabkan oleh keberadaan substrat pasir berlumpur dan pecahan karang pada stasiun 1 ini menunjang pertumbuhan spesies ini. Bengen (2004) menyatakan, Thalassia hemprichii tumbuh pada substrat pasir berlumpur dan pecahan karang sehingga jenis sangat mendominasi di stasiun 1 maupun ketiga zonanya pada perairan Pulau Buntal. Nilai kerapatan terendah ditemukan pada jenis Halophila ovalis sebesar 10,16 tegakan $/ \mathrm{m}^{2}$ dengan nilai kerapatan relatif $3 \%$.

Nilai kerapatan tertinggi dan kerapatan relatif pada statiun 2 didominasi oleh dua jenis lamun yaitu Thalassia hemprichii sebesar 76,83 tegakan $/ \mathrm{m}^{2}$ dan Enhalus acoroides sebesar 76,51 tegakan $/ \mathrm{m}^{2}$, dengan nilai kerapatan relatif masing-masing 43\% (Gambar 2). Berbeda dengan stasiun 1 yang didominasi oleh jenis lamun Thalassia hemprichii, pada stasiun dua jenis ini mengalami penurunan nilai kerapatan dikarenakan lokasi yang menghadap langsung dengan perairan luar teluk sehingga parameter fisik kimia maupun substrat juga berbeda. Nilai kerapatan terendah diwakili oleh jenis Cymodocea rotundata yaitu 5,40 tegakan $/ \mathrm{m}^{2}$ dengan nilai kerapatan relatifnya yaitu 3\%. Pada zona 1 stasiun 2 hanya ditemukan satu jenis lamun yaitu Enhalus acoroides, sedangkan pada zona 2 dan 3 didominasi jenis Thalassia hemprichii yang memiliki nilai kerapatan rendah jika dibandingkan dengan stasiun 1 .

\section{Frekuensi Jenis Lamun}

Nilai frekuensi kehadiran jenis lamun tertinggi yaitu pada jenis Thalassia hemprichii dan Enhalus acoroides. Jenis Thalassia hemprichii ditemukan pada 134 kuadran dari total 135 kuadran pada stasiun 1 sehingga memiliki nilai frekuensi kehadiran sebesar 0,99, sedangkan untuk jenis Enhalus acoroides ditemukan pada 128 kuadran dengan nilai frekuensi kehadiran sebesar 0,95. Nilai frekuensi terendah pada stasiun 1 yaitu pada jenis Halophila ovalis dengan nilai 0,37 dan frekuensi kehadiran relatifnya $10 \%$. Hal ini dikarenakan jenis Halophila ovalis hanya ditemukan pada 50 kuadran dari total 135 kuadran.

Tabel 1. Komposisi jenis lamun di perairan Pulau Buntal

\begin{tabular}{cccll}
\hline Kelas & \multicolumn{1}{c}{ Ordo } & \multicolumn{1}{c}{ Famili } & \multicolumn{1}{c}{ Genus } & \multicolumn{1}{c}{ Spesies } \\
\hline \multirow{4}{*}{ Angiospermae } & \multirow{3}{*}{ Helobiae } & Thalassia & T. hemprichii \\
& & & Halophila & H. ovalis \\
& & Enhalus & E. acoroides \\
\cline { 3 - 5 } & & \multirow{2}{*}{ Cymodoceaceae } & Cymodocea & $\begin{array}{l}\text { C. rotundata } \\
\text { C. serrulata }\end{array}$ \\
\hline
\end{tabular}




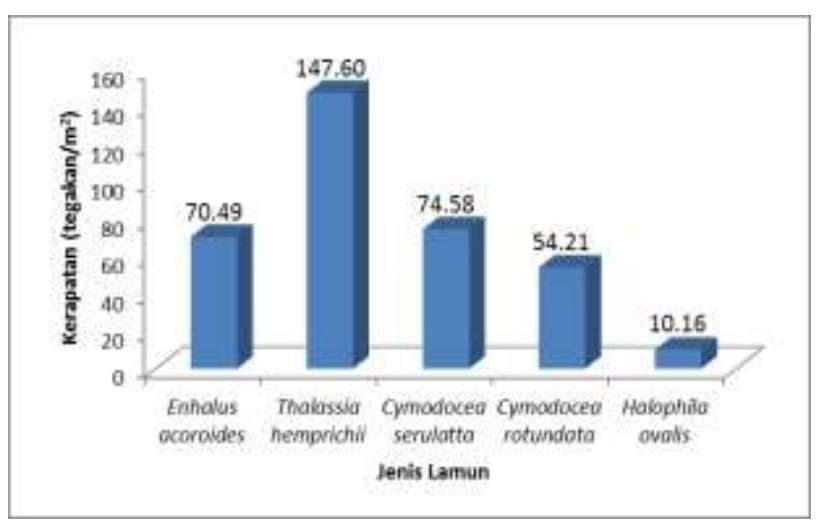

Gambar 2. Kerapatan jenis lamun stasiun 1

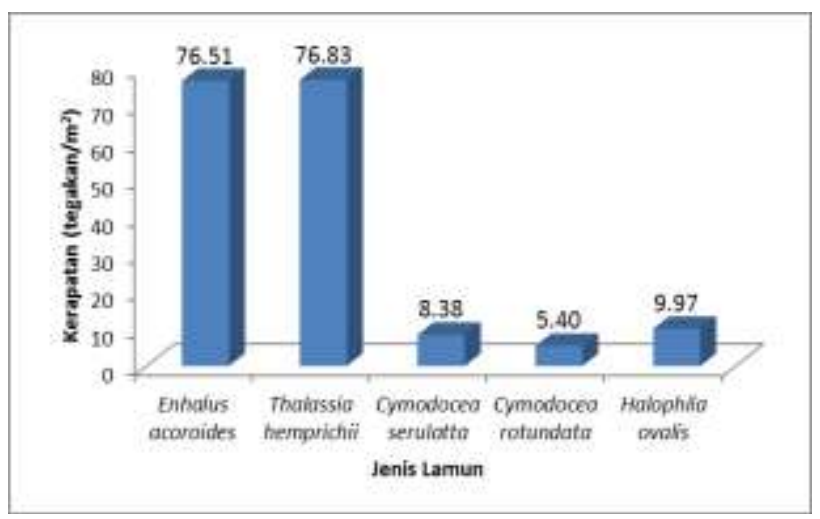

Gambar 3. Kerapatan jenis lamun stasiun 2

Pada stasiun 2 frekuensi kehadiran dan frekuensi kehadiran relatif jenis lamun yang tertinggi yaitu Enhalus acoroides dengan nilai 0,95 dan frekuensi kehadiran relatifnya $44 \%$. Jenis Enhalus acoroides ditemukan pada 60 kuadran dari total 63 kuadran pada stasiun 2 . Lamun jenis Halophila ovalis ditemukan pada 11 kuadran dari total kuadran pada stasiun 2 sehingga memiliki nilai frekuensi kehadiran terendah yaitu 0,17 dan nilai frekuensi kehadiran relatifnya $8 \%$.

\section{Persen Penutupan Jenis Lamun}

Berdasarkan persentase tutupan lamun yang ditemukan dari kedua stasiun, menunjukkan kondisi lamun di perairan Pulau Buntal dalam kondisi kurang sehat dan sehat (Keputusan Menteri Lingkungan Hidup No. 200 Tahun 2004). Kondisi lamun pada stasiun 1 memiliki tergolong sehat (tutupan baik) dengan tutupan $>60 \%$, sedangkan stasiun 2 tergolong kurang sehat (tutupan rusak) dengan tutupan $<59,99 \%$ (Gambar 4).

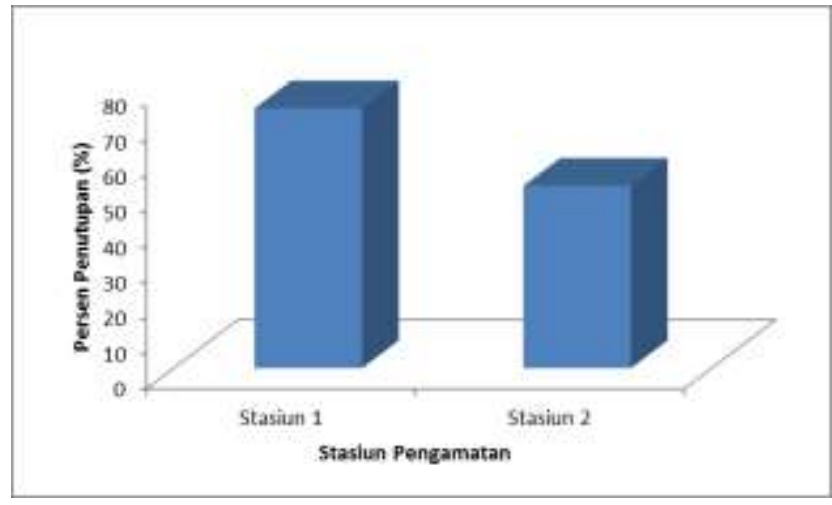

Gambar 4. Persen penutupan lamun pada tiap stasiun

\section{Komposisi Jenis Sumberdaya Teripang}

Berdasarkan hasil penelitian, diperoleh 11 jenis teripang yang tergolong dalam dua ordo yaitu Aspidochirotida dan Apodida (Tabel 2). Ordo Aspidochrotida terdiri dua famili yaitu Holothuriidae dan Stichopodidae. Family Holothuriidae terdiri atas dua genera yaitu Holothuria dan Bochadschia yang diwakili oleh lima spesies diantaranya spesies Holothuria atra, H. leucospilota, H. fuscogilva, $H$. scabra dan Bochadschia argus. Family Stichopodidae terdiri dua genera yaitu Stichopus dan Thelenota yang diwakili oleh tiga spesies yaitu spesies Stichopus variegatus, S. horrens dan Thelenota ananas. Ordo apodida terdiri dari satu family yaitu Synaptidae dengan satu genera yaitu Opheodesoma yang diwakili oleh tiga spesies yakni spesies Opheodesoma australiensis, $O$. clarki dan $O$. grisea.

\section{Kepadatan dan Potensi Sumberdaya Teripang Tiap Stasiun dan zona}

Pada stasiun 1 nilai kepadatan teripang tertinggi diwakili oleh spesies $H$. leucospilota dengan nilai kepadatan yaitu $0,129 \mathrm{ind} / \mathrm{m}^{2}$ dan potensi sebesar 2913.333 ind, kemudian diikuti jenis $H$. atra dan $S$. variegates yang memiliki nilai kepadatan dan potensi yang sama yaitu $0.129 \mathrm{ind} / \mathrm{m}^{2}$ dan potensinya sebesar 2086.667 ind (Tabel 3). Nilai kepadatan terendah diwakili oleh spesies $H$. scabra dengan nilai kepadatan yaitu $0.004 \mathrm{ind} / \mathrm{m}^{2}$ dan potensi sebesar 86.667 ind. Nilai kepadatan tertinggi pada ketiga zona di stasiun 1 diwakili oleh jenis $H$. leucospilota dengan kisaran nilai kepadatan yaitu 0,109 $\mathrm{ind} / \mathrm{m}^{2}$ hingga $0,146 \mathrm{ind} / \mathrm{m}^{2}$. Pada zona 1 nilai kepadatan terendah diwakili oleh jenis $O$. grisea 
yaitu $0,001 \mathrm{ind} / \mathrm{m}^{2}$ dan zona 2 diwakili oleh jenis $T$. ananas sebesar $0,003 \mathrm{ind} / \mathrm{m}^{2}$, sedangkan zona 3 diwakili oleh jenis $H$. scabra dengan nilai kepadatannya yaitu $0,003 \mathrm{ind} / \mathrm{m}^{2}$. Kedua jenis teripang $T$. ananas maupun $H$. scabra merupakan jenis teripang yang banyak dicari oleh para nelayan karena harganya yang mahal. Jenis-jenis ini banyak dijumpai di tempat budidaya teripang milik nelayan yang berada di sekitar perairan Pulau Buntal.

Berdasarkan hasil penelitian, pada stasiun 2 diperoleh nilai kepadatan dan potensi spesies teripang cukup bervariasi (Tabel 4). Nilai kepadatan total teripang tertinggi diwakili $H$. leucospilota sebesar $0,083 \mathrm{ind} / \mathrm{m}^{2}$ dan potensi sebesar 866,667 ind, diikuti oleh $H$. atra dengan nilai kepadatan $0,079 \mathrm{ind} / \mathrm{m}^{2}$ dan potensi sebesar 833,333 ind. Sementara kepadatan dan potensi terendah yaitu pada jenis $B$. argus dengan nilai kepadatan $0,01 \mathrm{ind} / \mathrm{m}^{2}$ dengan potensi sebesar 100 ind.

Kepadatan total suluruh jenis teripang tertinggi di stasun 2 terdapat pada zona 2 yaitu $0,445 \mathrm{ind} / \mathrm{m}^{2}$, dengan nilai kepadatan spesies tertinggi yaitu jenis $H$. atra sebesar 0,103 $\mathrm{ind} / \mathrm{m}^{2}$. Pada zona 3 stasiun 2 nilai total kepadatan seluruh jenis teripang yaitu 0,451 $\mathrm{ind} / \mathrm{m}^{2}$ dengan nilai kepadatan tertinggi diwakili jenis $H$. leucospilota yaitu 0,107 $\mathrm{ind} / \mathrm{m}^{2}$. Jenis teripang dengan nilai kepadatan terendah yaitu $H$. scabra dengan nilai kepadatannya $0,006 \mathrm{ind} / \mathrm{m}^{2}$. Sementara itu, zona 1 pada stasiun 2 merupakan zona dengan nilai kepadatan total terendah yaitu $0,345 \mathrm{ind} / \mathrm{m}^{2}$ dikarenakan memiliki substrat lumpur berpasir dan hanya ditumbuhi oleh satu jenis lamun saja (Enhalus acoroides).

Tabel 2. Komposisi jenis teripang di perairan Pulau Buntal

\begin{tabular}{|c|c|c|c|c|}
\hline Kelas & Ordo & Famili & Genus & Spesies \\
\hline \multirow{3}{*}{ Holothuroidea } & \multirow[t]{2}{*}{ Aspidochirotida } & Holothuriidae & $\begin{array}{l}\text { Holothuria } \\
\text { Bochadschia }\end{array}$ & $\begin{array}{l}\text { atra } \\
\text { leucospilota } \\
\text { fuscogilva } \\
\text { scabra } \\
\text { argus }\end{array}$ \\
\hline & & Stichopodidae & $\begin{array}{l}\text { Stichopus } \\
\text { Thelenota }\end{array}$ & $\begin{array}{l}\text { variegates } \\
\text { horrens } \\
\text { ananas }\end{array}$ \\
\hline & Apodida & Synaptidae & Opheodesoma & $\begin{array}{l}\text { australiensis } \\
\text { clarki } \\
\text { grisea }\end{array}$ \\
\hline
\end{tabular}

Tabel 3. Kepadatan dan potensi teripang pada stasiun 1

\begin{tabular}{clccc}
\hline Stasiun 1 & \multicolumn{1}{c}{ Spesies } & Jumlah Individu & Kepadatan (Ind/ $\mathbf{m}^{\mathbf{2}}$ ) & Potensi (Ind) \\
\hline 1 & H. atra & 313 & 0.093 & 2086.667 \\
2 & H. leucospilota & 437 & 0.129 & 2913.333 \\
3 & H. fuscogilva & 123 & 0.036 & 820 \\
4 & H. scabra & 13 & 0.004 & 86.667 \\
5 & B. argus & 29 & 0.009 & 193.333 \\
6 & S. variegates & 313 & 0.093 & 2086.667 \\
7 & S. horrens & 86 & 0.025 & 573.333 \\
8 & T. ananas & 145 & 0.006 & 133.333 \\
9 & O. australiensis & 243 & 0.043 & 966.667 \\
10 & O. clarki & 48 & 0.072 & 1620.000 \\
11 & O. grisea & 1770 & 0.014 & 320.000 \\
\hline
\end{tabular}


Tabel 4. Kepadatan dan potensi teripang pada stasiun 2

\begin{tabular}{clccc}
\hline Stasiun 2 & \multicolumn{1}{c}{ Spesies } & Jumlah Individu & Kepadatan $\left(\mathbf{I n d} / \mathbf{m}^{\mathbf{2}}\right)$ & Potensi $($ Ind) \\
\hline 1 & H. atra & 125 & 0.079 & 833.333 \\
2 & H. leucospilota & 130 & 0.083 & 866.667 \\
3 & H. fuscogilva & 64 & 0.041 & 426.667 \\
4 & H. scabra & 9 & 0.006 & 60.000 \\
5 & B. argus & 15 & 0.010 & 100.000 \\
6 & S. variegates & 104 & 0.066 & 693.333 \\
7 & S. horrens & 45 & 0.029 & 300.000 \\
8 & T. ananas & 18 & 0.011 & 120.000 \\
9 & O. australiensis & 53 & 0.034 & 353.333 \\
10 & O. clarki & 71 & 0.045 & 473.333 \\
11 & O. grisea & 23 & 0.015 & 153.333 \\
\hline \multicolumn{6}{r}{ Total } & 657 & 0.417 & 4379.999 \\
\hline
\end{tabular}

\section{Frekuensi Kehadiran Spesies Teripang Tiap Stasiun dan Zona}

Nilai frekuensi kehadiran tertinggi pada stasiun 1 yaitu Holothuria atra dengan nilai frekuensi kehadiran sebesar 0,889 dan nilai frekuensi relatif 17,7 . Jenis $H$. leucospilota memiliki nilai frekuensi kehadiran sebesar 0,887 dan frekuensi relatif $17,257 \%$, sedangkan untuk spesies $H$. scabra memiliki nilai frekuensi kehadiran sebesar 0,089 dan frekuensi relatif 1,77\%. Pada stasiun 2, frekuensi kehadiran jenis $H$. atra sebesar 0,852 dengan frekuensi relatif $16,251 \%$, diikuti oleh $H$. leucospilota dengan nilai frekuensi kehadiran sebesar 0,810 dan frekuensi relatif $15,953 \%$. Spesies dengan nilai frekuensi kehadiran terendah yaitu $H$. scabra dengan nilai frekuensi kehadiran sebesar 0,143 dan frekuensi relatif $2,813 \%$.

\section{Distribusi Spasial Teripang Pada Ekosistem Lamun}

Stasiun 1 yang terletak di bagian timur Pulau Buntal mempunyai tipe substrat campuran yang didominasi pasir berlumpur (Gambar 5). Kedalaman perairan yang relatif dangkal serta kerapatan lamun yang sangat tinggi yang ditemukan tersambung hingga Pulau Tatumbu, mengakibatkan teripang yang ditemukan juga banyak terutama jenis H.atra dan $H$. leucospilota.

Stasiun 2 terletak di bagian barat Pulau Buntal (Gambar 6), mempunyai tipe substrat campuran lumpur berpasir dan pasir berlumpur dengan topografi perairan yang berbeda yaitu mulai dari perairan dangkal hingga perairan dalam. Lamun yang tumbuh hanya ditemukan pada perairan dangkal. Kehadiran teripang di stasiun ini relatif rendah diduga juga karena daerah ini terkena ombak. Substrat dominan lumpur berpasir ditemukan pada tepi pulau dan pasir berlumpur ditemukan ke arah laut. Kerapatan lamun yang rendah dan Kondisi tutupan lamun termasuk kategori rusak mengakibatkan teripang yang ditemukan juga relatif lebih rendah dibandingkan pada stasiun 1 .

Terdapat 3 jenis dari 11 jenis teripang yang ditemukan di Perairan Pulau Buntal, menempel atau berdampingan langsung dengan kelima jenis lamun. Jenis teripang $H$. atra sebesar $40 \%$ ditemukan hidup berdampingan dengan jenis lamun $E$. acoroides dan diikuti $T$. hemprici sebesar $38,14 \%$. Jenis $H$. leucospilota berasosiasi tinggi dengan jenis lamun $T$. hemprici yaitu $47,01 \%$ sedangkan $S$. variegates sebesar 47,52\% pada jenis lamun yang sama yaitu T. hemprici. Oedjoe\&Eoh (2015), menyatakan bahwa teripang lebih menyukai habitat dengan dasar perairan pasir atau pasir berlumpur yang ditumbuhi lamun. Lamun memegang peranan penting dalam pendauran berbagai zat hara dan elemen-elemen yang ada di lingkungan laut, khususnya zat-zat hara yang dibutuhkan oleh algae epifitik (Azkab, 1999). 


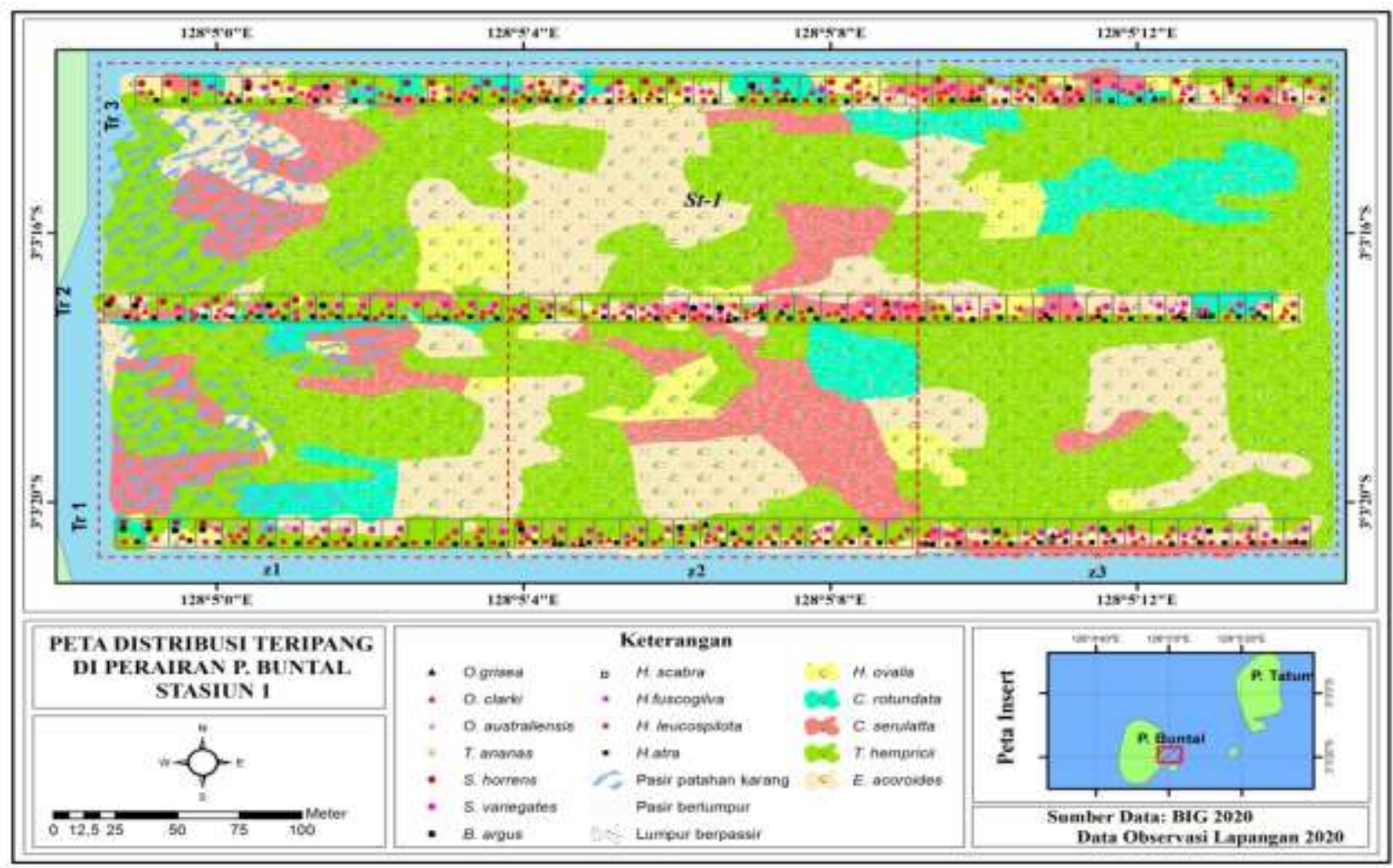

Gambar 5. Peta distribusi spasial teripang pada ekosistem lamun stasiun 1

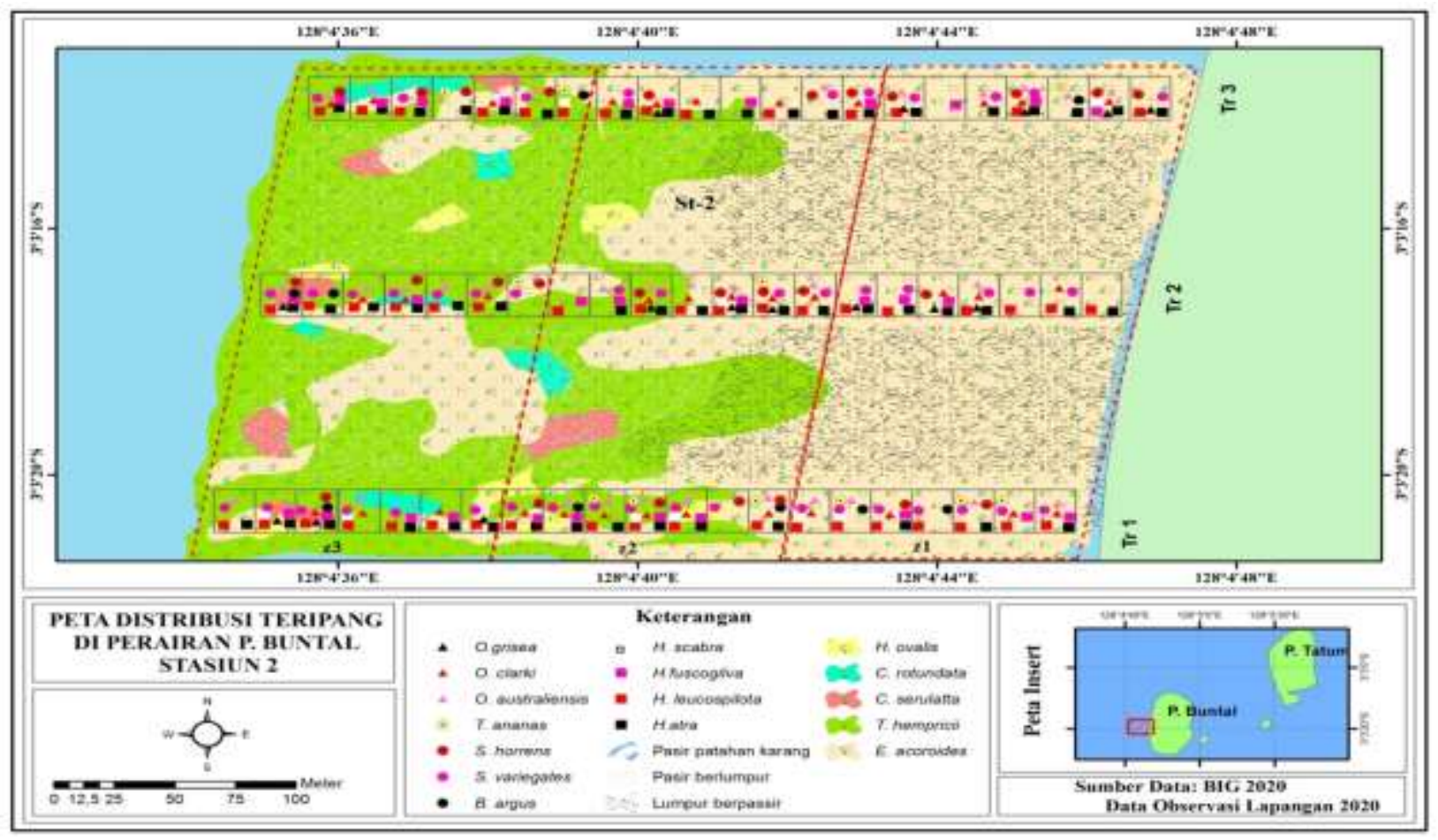

Gambar 6. Peta distribusi spasial teripang pada ekosistem lamun stasiun 2 


\section{Hubungaan Kepadatan Teripang Dengan Kerapatan Lamun}

Hubungan antara kepadatan teripang dengan kerapatan lamun membentuk persamaan $\mathrm{y}=0,0006 \mathrm{x}+0,3199$ (Gambar 7). Nilai koefisien korelasi (r) sebesar 0,8478 dan koefisien determinasi (R) sebesar 0,7186. Berdasarkan analisa hubungan kepadatan teripang dengan kerapatan lamun pada Perairan Pulau Buntal diperoleh adanya hubungan yang tinggi. Menurut Astuti (2017) besar koefisien korelasi antara 0,71-0,99 termasuk yang memiliki korelasi tinggi. Sehingga dapat dikatakan bahwa kepadatan teripang berhubungan erat dengan kerapatan lamun. Nilai $R$ sebesar 0,7186 menunjukan bahwa $71,86 \%$ kerapatan lamun mempengaruhi kelimpahan teripang, sedangkan sisanya dipengaruhi oleh faktor lainnya. Diketahui setiap peningkatan 1 kerapatan lamun akan meningkatkan kepadatan teripang sebesar 0,0006 ind dengan kondisi faktor lain tetap. Dapat dikatakan pula bahwa semakin rapat padang lamun, kepadatan teripang pada padang lamun tersebut juga meningkat.

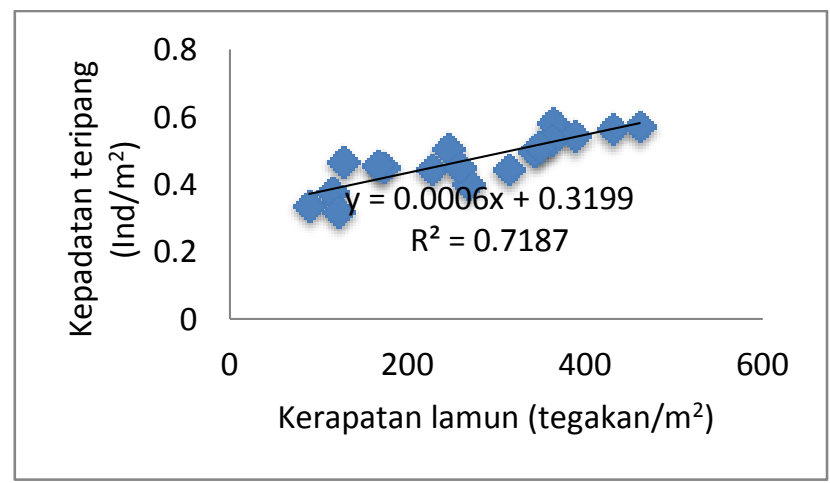

Gambar 7. Grafik hubungan antara kepadatan teripang dengan kerapatan lamun

Berdasarkan perhitungan diatas dapat disimpulkan bahwa dengan derajat kesalahan penarikan kesimpulan sebesar (alpha) 0,05 dimana nilai $t$ tabel adalah 2,10982 dengan hasil uji t hitung yaitu 6,39324. Berdasarkan nilai tersebut maka $t$ hitung $>t$ tabel sehingga dapat disimpulkan berdasarkan hipotesis yang dikembangkan yakni terima Ha (ada hubungan antara kepadatan teripang dengan kerapatan lamun. di perairan Pulau Buntal-Teluk Kotania, Kabupaten Seram Bagian Barat.

\section{KESIMPULAN DAN SARAN}

Berdasarkan hasil penelitian yang telah dikemukakan maka dapat disimpulkan sebagai sebagai berikut:

1. Nilai parameter lingkungan yang diperoleh menunjang pertumbuhan lamun dan teripang.

2. Kondisi lamun pada stasiun 1 dikategorikan sehat (tutupan baik), sedangkan pada 2 termasuk kategori kurang sehat (tutupan rusak).

3. Teripang yang ditemukan pada kedua stasiun pengamatan tergolong dalam dalam dua ordo, tiga famili, lima genera dan sebelas spesies. Nilai kepadatan dan fekuensi kehadiran tertinggi diwakili oleh jenis Holothuria leucospilota diikuti H.atra, sedangkan nilai kepadatan dan frekuensi kehadiran terendah pada jenis H.scabra.

4. Sebagian besar spesies teripang ditemukan dominan pada habitat pasir berlumpur yang berasosiasi dengan lamun. Adapun dari kesebelas jenis teripang, sebanyak enam jenis memiliki nilai presentase tertinggi berasosiasi dengan lamun Enhalus acoroides dan lima jenis teripang lainnya pada jenis lamun Thalasia hempricii.

5. Terdapat hubungan yang tinggi antara kepadatan teripang dengan kerapatan lamun di perairan Pulau Buntal, sehingga semakin tinggi kerapatan lamun akan diikuti oleh tingginya kepadatan teripang.

Berdasarkan hasil penelitian dan observasi lapangan, maka disarankan agar ada penelitian lanjutan yang mengkaji tentang produktivitas primer, faktor lingkungan berupa nitrat dan fosfat serta perubahan luasan lamun maupun faktor-faktor lain yang mempengaruhi kelimpahan teripang.

\section{DAFTAR PUSTAKA}

Astuti, C.C. 2017. Analisis Korelasi Untuk Mengetahui Keeratan Hubungan antara Keaktifan Mahasiswa Dengan Hasil Belajar Akhir. Journal of Information Computer Technology Education 1(1): 1-7.

Ati, R.N.A., T.L. Kepel, M.A. Kusumaningtyas, D.M.H. Mantiri, A.A. Hutahaean. 2016. Karkteristik dan Potensi Perairan Sebagai 
DOI: https://doi.org/10.30598/TRITONvol16issue2page84-96

Pendukung Pertumbuhan Lamun di Perairan Teluk Buyat dan Teluk Ratatotok, Sulawesi Utara. Jurnal Manusia dan Lingkungan 23(3): 342-348.

Azkab, M. H. 1999. Struktur dan Fungsi Pada Komunitas Lamun. Jakarta; Balitbang Biologi Laut, Puslitbang Oseanologi 25 (3): 1-7.

Azkab, M, H. 2006. Ada Apa Dengan Lamun. Jakarta; Bidang Sumberdaya Laut, Pusat Penelitian Oseanografi-LIPI. Vol 31 (3): 4555.

Badria, S, 2007. Laju Pertumbuhan Daun Lamun (Enhalus acoroides) pada Dua Substrat yang Berbeda di Teluk Banten. Skripsi. Fakultas Perikanan dan Ilmu Kelautan, IPB. Bogor.

Bengen, D.G. 2004. Sinopsis Ekosistem dan Sumber Daya Alam Pesisir Dan Laut Prinsip Pengelolaannya. Pusat Kajian Sumber Daya Pesisir dan Lautan, Institut Pertanian Bogor.

Cannon, L. R. G. \& H. Silver. 1987. Sea Cucumber of Nothern Australia. Queensland Museum, South Brisbane: vii $+60 \mathrm{hlm}$.

Clark A. M. \& Rowe F. W. E. 1971. Monograph of Shallow-water Indo-West Pacific Echinoderms. No. 690. British Museum. pp. 238.

Dahuri, R., J. Rais, S.P. Ginting. 2001. Pengelolaan Sumber Daya Wilayah Pesisir dan Lautan Secara Terpadu. PT. Pradnya Paramita. Jakarta.

Darsono, P. 2003. Sumberdaya Teripang dan Pengelolaannya. Oseana XXVIII (2): 1-9. ISSN 0216-1877.

Den Hartog, C., 1970. The Sea Grasses of the World. North Holand Publishing Company. Amsterdam, 275p.

English, S., Wilkinson, C., dan Baker, V. 1997. Survey Manual for Tropical Marine Resources, 2nd Edition. Townsville: Australian Institute of Marine Science.

Jalaluddin, M., I.N. Octaviyani, A.N.P.Putri, W. Octaviyani, I. Aldiansyah. 2020. Padang Lamun Sebagai Ekosistem Penunjang Kehidupan Biota Laut di Pulau Pramuka, Kepulauan Seribu, Indonesia. Jurnal Geografi Gea 20(1): 44-53.

Keputusan Menteri Negara Lingkungan Hidup (KEPMEN-LH)) Nomor 200 Tahun 2004. Kriteria Baku Kerusakan dan Pedoman Penentuan Status Padang Lamun.

Keputusan Menteri Negara Lingkungan Hidup (KEPMEN-LH)) Nomor 51 Tahun 2004. Baku Mutu Air Laut.

Khouw, A.S. 2009. Metode dan Analisa Kuantitatif dalam Bioekologi Laut. Jakarta : PPLP.
Komala, R. 2015. Keanekaragaman Teripang Pada Ekosistem Lamun dan Terumbu Karang di Pulau Bira Besar, Kepulauan Seribu, Jakarta. Pros. Sem. Nas. Masy. Biodiv. Indonesia 1(2): 222-226. DOI: $10.13057 / \mathrm{psnmbi} / \mathrm{m} 010209$.

Kordi, M.G.H. 2010. Cara Gampang Membudidayakan Teripang. Penerbit ANDI. Yogyakarta. Hal. 122.

Kordi, M.G.H. 2011 Ekosistem Lamun (Seagrass): Fungsi, Potensi dan Pengelolaan. Rineka Cipta. Jakarta.

Laksana, M.J., B. Sulardiono, A. Solichin. 2019. Kelimpahan Teripang (Holothuroidea) Berdasarkan Kerapatan Lamun di Pantai Prawean Desa Bandengan, Jepara. Journal of Maquares 8(4): 337-346.

Latuconsina, H., A. R. Lestaluhu dan M. A. Al'aidi. 2014. Sebaran Spasio-Temporal Komunitas Ikan Padang Lamun Perairan Pulau BuntalTeluk Kotania, Seram Barat. In AA. Atmadipoera (eds). Prosiding PIT-ISOI X 2013. Ikatan Sarjana Oseanologi Indonesia. Jakarta. pp. 280-295.

Lewerissa, Y A. 2014. Studi Ekologi Sumberdaya Teripang di Negeri Porto Pulau Saparua Maluku Tengah. Biopendix 1(1): 32-42.

Marsoedi, L. F. Mulyani, Guntur. 2020. Identifikasi Kesesuaian Lahan Budidaya Teripang Pasir (Holothuria scabra) Berdasarkan Parameter Kimia Menggunakan Sistem Informasi Geografis di Perairan Lombok Barat. Jurnal Perikanan 10(1): 1-7. DOI: https://doi.org/10.29303/jp.v10i1.198.

Martoyo, J., Aji. N., Winanto, T. 2006. Budidaya Teripang. Edisi Revisi. Jakarta: Penebar Swadaya.

Odum, E.P. 1971. Fundamental of Ecology. 3rd ed. W.B. Saundes Company. Tokyo, Japan. 574 hal.

Oktamalia, D. Purnama, D. Hartono. 2016. Studi Jenis dan Kelimpahan Teripang (Holothuroidea) di Ekosistem Padang Lamun Perairan Desa Kahyapu Pulau Enggano. Jurnal Enggano 1(2): 56-63.

Oedjoe, M.D.R. \& C. B. Eoh. 2015. Keanekaragaman Timun Laut (Echinodermata: Holothuroidea) di Perairan Sabu Raijua, Pulau Sabu, Nusa Tenggara Timur. Jurnal Ilmu dan Teknologi Kelautan Tropis 7(1): 309-320.

Padang, A., M. sangadji, E. Lukman, R. Subiyanto. 2017. Pertumbuhan dan Kelulusan Hidup Teripang Pasir (Holothuria scabra) yang Dipelihara di Keramba Jaring Apung. 
TRITON: Jurnal Manajemen Sumberdaya Perairan 13(2): 115-124.

Parawansa, B.S., I. F. Ningsih, S.B.A. Omar. 2020. Biodiversitas Lamun di Perairan Kepulauan Tonyaman, Kabupaten Polewali Mandar. Prosiding Simposium Nasional VII Kelautan dan Perikanan. Fakultas Ilmu Kelautan dan Perikanan Universitas Hasanuddin, Makasar. ISBN 978-602-71759-7-6.

Poedjirahajoe, E., N.O.D. Mahayani, B. R. Sidharta, M.Salamuddin. 2013. Tutupan Lamun dan Kondisi Ekosistemnya di Kawasan Pesisir Madasanger, Jelenga dan Maluk, Kabupaten Sumbawa Barat. Jurnal Ilmu dan Teknologi Kelautan Tropis. 5(1):36-46. ISSN 20879423.
Riniatsih, I. 2016. Struktur Komunitas Larva Ikan pada Ekosistem Padang Lamun di Perairan Jepara. Jurnal Kelautan Tropis 19(1): 21-28.

Satria, G. G. A., Sulardiono, B., dan Purwanti, F. 2014. Kelimpahan Jenis Teripang Di Perairan Terbuka dan Tertutup Pulau Panjang Jepara, Jawa Tengah. Diponegoro Journal of Maqueres 3(1): 108-115.

Suryaningrum, T.D. 2008. Teripang: Potensinya Sebagai Bahan Nutraceutical dan Teknologi Pengolahannya. Squalen 3(2): 63-69.

Wawo M, Wardiatno Y, Adrianto L, Bengen D.G. 2014. Carbon Stored on Seagrass Community in Marine Nature Tourism Park of Kotania Bay, Western Seram, Indonesia. Journal of Tropical Forest Management. Vol.XX, (1):51-57, April 2014. EISSN: 2089-2063. DOI: $10.7226 / \mathrm{jtfm} .20 .1 .51$. 